\title{
MICHAEL DAVITT'S WARTIME VISIT TO SOUTH AFRICA (MARCH-MAY 1900) AND ITS CONSEQUENCES
}

\author{
Donal P. McCracken \\ University of KwaZulu-Natal
}

\begin{abstract}
In view of renewed interest in the radical Irish nationalist leader and land reform agitator Michael Davitt and his ideas, this article reconsiders his much publicised fact-finding visit to the war-torn Boer republics in South Africa and its context. Davitt resigned as an Irish nationalist member of parliament (MP) from the British House of Commons over the Anglo-Boer War, rather than any Irish issue. He was in South Africa from late March to early May 1900, where he met the leaders of the republics and senior generals. On his return to Ireland, Davitt wrote a 600-page partisan book on the Anglo-Boer War. The South African experience remained special to him. After his return to Europe, Davitt became closely associated with the Kruger-exile coterie, drifting away from mainline Irish nationalism. This article traces Davitt's visit and discusses the effect it had on him, on Irish nationalism and on the Boer republics he visited.
\end{abstract}

Keywords: Michael Davitt, Ireland, South Africa, Anglo-Boer War.

\section{Introduction}

Michael Davitt visited the South African Republic in 1900, following his resignation as an MP for an Irish constituency in the British parliament, ostensibly in protest over the British conflict against the Boer republics in the Anglo-Boer War. ${ }^{1}$ His declared purpose for the trip was to report for the press on the conflict and to collect material for a book on the war. ${ }^{2}$ As TW Moody's scholarly biography of Davitt (published in 1982) covered only the first 36 years of Davitt's life, the South African conflict was excluded. ${ }^{3}$ Davitt's pro-Boer activities and sympathies were discussed in several studies by Donal McCracken but not in the context of his full life until 2007 when Laurence Marley's Davitt biography surveyed the development of his ideological thinking. Then in 2016, Carla King's detailed 728-page study appeared, focusing on Davitt from 1882 until his death in 1906 and containing a chapter specifically on South Africa. ${ }^{4}$ These and other works examining Davitt's legacy invite a reappraisal of Davitt's African trip and his own tendentious narrative of the event. 


\section{Part 1: The saga}

For a politician who was regarded as a radical and who maintained an interest in socialism, it is ironic that the only contact Michael Davitt had with Southern Africa before the Anglo-Boer War period was in July 1896 when, with four others, he was part of a syndicate called the British and Irish Mining and General Finance Corporation Ltd. This was a prospecting venture in Southern Africa, including Matabeleland, and it proved to be a failure. Davitt had occasionally voiced general opposition to British imperial endeavours but, unlike those of his fellow-Irish MP, JG Swift MacNeill, his objections were not frequent or particularly fervent. ${ }^{5}$ However, the establishment of the Irish Transvaal Committee in Dublin by Arthur Griffith and Maud Gonne in September 1899 changed that. This heralded the birth of the Irish pro-Boer movement as a political vehicle attempting to drive the advanced Irish nationalist cause by aiming to undermine British army recruitment in Ireland and celebrating the early victories of the Boers over the British military in South Africa. ${ }^{6}$ Half-hearted attempts were also made to recruit and send fighters as well as an Irish ambulance unit from Ireland to join the Boers, a historic throwback to a similar attempt during the FrancoPrussian War. ${ }^{7}$ The ensuing reality was somewhat different from such plans, not least because it became obvious from March 1900 that the fortunes of this war in Africa were shifting in favour of the British. The presence of 11 Irish regiments in the British army and one Irish yeomanry battalion numbering some 30000 men did not assist the Irish nationalist cause. Even so, much publicity was given to the activities of two Irish commandos, ${ }^{8}$ consisting primarily of Irish miners on the Witwatersrand, along with an armed 'ambulance corps' of 50 American Irish. ${ }^{9}$

The most public achievements of the pro-Boer movement in Ireland were the rallies and the poster campaign successfully run in Dublin, Limerick and Cork. Politically, the Irish pro-Boers created a neutral cause around which Irish parliamentary nationalism could unite after a decade of discord following the Parnell split. This was a convenient bandwagon propelled by a great deal of 'my enemy's enemy is my friend' rhetoric. Irish settlement had existed in South Africa since the late eighteenth century, although it was numerically small and based on a middle-class and skilled artisan foundation, unlike the Irish diaspora pattern in North America or Australia. ${ }^{10}$ This pattern was also disrupted in the mid to late 1890s when depression in Ireland and job opportunities on the gold mines around Johannesburg led to a temporary influx of Irishmen. These included the future Sinn Fein founder Arthur Griffith (who returned home in 1898) and John MacBride, who subsequently established the $1^{\text {st }}$ Irish Transvaal Brigade and was eventually shot by the British following the 1916 Rising in Dublin. ${ }^{11}$

This is not to say that many Irish nationalists did not have a genuine sympathy for the Boer farmers, as indeed many did a hundred years later for the Irish AntiApartheid Movement. The centre of Dublin became a venue for pro-Boer rallies and the occasional riot, with the flag of the South African Republic, the Vierkleur ('fourcoloured flag'), flying defiantly, and parts of the city out of bounds at night for British soldiers, though not the Dublin Metropolitan Police. Meanwhile, at Westminster, the fragmented Irish nationalist MPs united around the republican cause in South Africa. ${ }^{12}$ 
Davitt, MP for South Mayo since $1895,{ }^{13}$ was happy to appear at a pro-Boer rally in Dublin on 1 October 1899, but was uneasy at Westminster. As an advanced nationalist from a peasant background, he was an outsider even to most of his Irish colleagues in the middle-class milieu of the nationalist Irish Parliamentary Party. ${ }^{14}$

Davitt's unhappiness at Westminster was reflected in his contribution to the main Irish assault on the war in the House of Commons debate commencing on 17 October 1899, six days after war had been declared. His speech in that war debate was a strange hotchpotch of bitterness, self-pity at how the Commons had treated him and the wrongs done by the English to the Boers and to the Irish. Repudiating the accusation of being a traitor, he cited Washington, O'Connell and Parnell as having all been awarded this same distinction. This was somewhat opportunistic reframing, given Davitt's role only a few years earlier in the fall of the Irish leader, Charles Stewart Parnell. In the peroration of his war speech, Davitt proclaimed his preferred epitaph:

Here lies a man who from his cradle to his grave was considered by his foes a traitor to alien rule and oppression in Ireland and in every land outside her shores. ${ }^{15}$

This might appear rather disingenuous from the man who a few years earlier had befriended, or allowed himself to be befriended, by both John Morley, the chief secretary of Ireland, and John Mallon, head of the Dublin Metropolitan Police's detective division. "A remarkable man", Morley had enthused about Davitt. "What a change in ten years - the Fenian convict walking up the avenue of this Lodge, arm-inarm with the Chief Secretary."16 Davitt did oscillate between the two worlds of Irish moderate and advanced nationalism, blowing backwards and forwards from one to the other.

On 25 October 1899, a week after his first intervention, and just two weeks after the Anglo-Boer War had commenced, Davitt rose again in the House of Commons in a war requisition debate. Stating that he would not "purchase liberty for Ireland at the base price of voting against liberty in South Africa", he announced that he would resign as the MP for South Mayo. He asserted, "no cause, however just, will find support, no wrong, however pressing or apparent, will find redress here, unless backed up by force" ${ }^{17} \mathrm{He}$ presented his departure as a protest against the war against the Boer republics, and later he reiterated this in the preface of his book on the South African war. ${ }^{18}$ This was true but it was also a smokescreen for a multitude of other contributing reasons. These included -

- Davitt's growing cynicism about the efficacy of parliamentary nationalism;

- uneasiness at being part of the Westminster set-up ("a pack of drunken rascals"19) and even of his own Irish party;

- a lingering embarrassment that he had betrayed the American lobby and the advanced nationalist cause by ever agreeing to be part of the constitutional movement; and, 
- if the newspaper The Nation is to be believed, chagrin that he had not been elected secretary of the Mayo county council.

The Irish police were perhaps not so far off the mark when they claimed that Davitt had already determined to leave Westminster before the South African excuse offered itself. ${ }^{20}$ To William O'Brien, Davitt confided in January 1900 that he had a "bad attack of the political blues" and that he and O'Brien would be "in Glasnevin [Cemetery] by the time this wretched country will make up its mind to help itself". ${ }^{21}$ In short, the reality was that Davitt was disenchanted with Irish politics.

It was one thing publicly supporting the Boers, though, and another to visit them while they were engaged in a life-or-death struggle with the British in a formal fullscale war. Davitt, however, might have construed his plans as a mischievous way of complying with advice to spend some time in a warm climate to improve his health. Impecunious as ever, he also hoped that writing a book on the war from the Boer point of view would make him some money. As he was about to leave Europe, freelancing opportunities also appeared, offering him some more immediate income by writing on his exploits for the Freeman's Journal as well as for the New York Journal. These were, though, fortuitous and had not initiated the idea of his African adventure.

\section{The voyage}

Davitt would be away from Ireland for four months. He sailed on the 20-year-old and rather dilapidated 4 000-ton Oxus from Marseilles on Sunday, 25 February 1900. ${ }^{22}$ He paid for his own ticket, having borrowed $£ 250$ for his trip. The Dublin police noted of his departure, "[h]e is in poor circumstances." ${ }^{23}$ None of the large sums of cash injected by Boer agents into the Irish cause had found their way to Davitt at this stage.

The captain of the Oxus, Davitt wrote, had a startling resemblance to the late Irish-American journalist, poet and Fenian John Boyle O'Reilly (1844-1890). Davitt recorded in his diary, "[t]he Oxus does not improve after a night's experience. But big trading sea ships cannot be expected to be as spic[k] \& span as a trans-Atlantic liner." He was determined that he was on an adventure. There were even, he was sure, volunteer Boer fighters on board. He was correct in that a couple of passengers were young men from Belfast travelling to join MacBride's commando, but it seems they kept their distance from Davitt. Baron Van Dedem, a Dutch politician whose sister was married to the famous Irish historian WEH Lecky, soon befriended Davitt. ${ }^{24}$ At Diego Suarez, on the north coast of Madagascar, Davitt and Baron Van Dedem transferred for the last lap onto the Gironde, ${ }^{25}$ and after a month-long, "fatiguing voyage" Davitt arrived at Lourenço Marques (Maputo) on 24 March 1900. ${ }^{26}$

By the next day, his $54^{\text {th }}$ birthday, he was on a steam train travelling across the Highveld. On arrival at Pretoria railway station, Davitt heard a voice shout out, "Is Mr Davitt on this train?" It was no less a personage than State Secretary Reitz. Van Dedem soon ingratiated himself into the party, which went to the Grand Hotel in Church Square. The enigmatic Irish-American Colonel John Blake, the leader of the 
$1^{\text {st }}$ Irish Transvaal Brigade, also stayed at the Grand when in Pretoria, as did many war correspondents. ${ }^{27}$ So did some other Irish commando members when they could, though as the British army came nearer and nearer, the Irish lines of credit in the hotel's well-stocked bar became shorter and shorter.

Michael Davitt's South African itinerary is summarised in Table 1.

Table 1: Davitt's schedule ${ }^{28}$

\begin{tabular}{|c|c|}
\hline Date & Event \\
\hline \multicolumn{2}{|c|}{ February 1900} \\
\hline 25 & Sails from Amsterdam on SS Oxus \\
\hline \multicolumn{2}{|c|}{ March 1900} \\
\hline 21 & Arrives Beira \\
\hline 25 & $54^{\text {th }}$ birthday \\
\hline 26 & $\begin{array}{l}\text { Arrives Lourenço Marques } \\
\text { Train to Pretoria }\end{array}$ \\
\hline 27 & $\begin{array}{l}\text { Meets President Paul Kruger } \\
\text { Meets Major John MacBride, second in command of the } 1^{\text {st }} \\
\text { Irish } \\
\text { Transvaal Commando } \\
\text { Train to Kroonstad } \\
\text { Meets Colonel De Villebois-Mareuil, "by far the ablest" } \\
\text { foreign officer }{ }^{29}\end{array}$ \\
\hline \multicolumn{2}{|c|}{ April 1900} \\
\hline 3 & $\begin{array}{l}\text { Train to Pretoria } \\
\text { Visits prisoner of war (POW) camp } \\
\text { Dinner with State Secretary Reitz, Sunnyside (Pretoria) }\end{array}$ \\
\hline 4 & $\begin{array}{l}\text { Letter to Irish nationalist leader John Dillon: "this war has } \\
\text { scarcely yet begun"30 }\end{array}$ \\
\hline 8 & $\begin{array}{l}\text { Carriage ride with 'Irish-Afrikaner' Solomon Gillingham, } \\
\text { during which Davitt meets Colonel John Blake (leader of the } \\
1^{\text {st }} \text { Irish commando) and two ladies, all on horseback }{ }^{31}\end{array}$ \\
\hline $10 \& 11$ & $\begin{array}{l}\text { Train to Kroonstad } \\
\text { Meets President Steyn } \\
\text { To Smaldeel and the Boer front line }\end{array}$ \\
\hline 12 & $\begin{array}{l}\text { To Brandfort } \\
\text { Meets General De la Rey } \\
\text { Meets General Philip Botha }\end{array}$ \\
\hline
\end{tabular}




\begin{tabular}{|c|c|}
\hline 13(Good Friday) & $\begin{array}{l}\text { Visits camps of the American Scouts, Hollander Corps and } \\
\text { State Artillery }\end{array}$ \\
\hline 16 & $\begin{array}{l}\text { From top of koppie (hill) views extensive British military } \\
\text { camp outside Bloemfontein } \\
\text { Meets General Kolbe } \\
\text { Meets Colonel Maximov }\end{array}$ \\
\hline 21 & $\begin{array}{l}\text { Meets President Steyn for } 20 \text { minutes } \\
\text { Train to Pretoria } \\
\text { Meets Colonel Arthur Lynch of the } 2^{\text {nd }} \text { Irish Transvaal } \\
\text { Commando } \\
\text { Meets members of the Irish-American Ambulance Corps }\end{array}$ \\
\hline 25 & $\begin{array}{l}\text { Writes to John Dillon that this was the most interesting } \\
\text { experience of his whole life. }\end{array}$ \\
\hline 26 & Tea with Captain and Mrs Oates (Johannesburg) \\
\hline \multicolumn{2}{|l|}{ May 1900} \\
\hline Early May & $\begin{array}{l}\text { Train to Dundee } \\
\text { Visits camp of } 2^{\text {nd }} \text { Irish commando }\end{array}$ \\
\hline 7 & $\begin{array}{l}\text { Attends last sitting of the Transvaal Volksraad (Pretoria): } \\
\text { "The dying session of a murdered nation's parliament." }{ }^{2} \\
\text { Meets General Ben Viljoen }\end{array}$ \\
\hline 15 & Train to Lourenço Marques \\
\hline 22 & Sails on SS Gironde \\
\hline 25 & Arrives in Marseilles \\
\hline
\end{tabular}

Not surprisingly, many of the republics' notables met Davitt. The list reads like a who's who, headed by both state presidents, Kruger and Steyn, although the latter could spare him only 20 minutes. Then there were Generals De la Rey, De Wet and Kolbe, as well as both Generals Jannie Smuts and Tobias Smuts. Davitt met General Louis Botha but was more interested by his brother, General Philip Botha, who was subsequently killed, and to whose memory Davitt dedicated his South African war book. Mr Justice GT Morice of the Transvaal Supreme Court, who was a Scot and regarded by some as a jingo, left his card for Davitt, although it is doubtful whether they met. Davitt did meet Colonel Stephanus Trichardt of the State Artillery, who had been in charge of the Irish commando outside Ladysmith, as well as General Ben Viljoen, who was a particularly good friend of the Irish in the Boer army. Davitt met the second-generation South African Irishman Solomon Gillingham, who ran a bakery in Pretoria notorious for its hard biscuits. Gillingham was a confidant of President Kruger, possessed a government supply concession, and was closely involved in setting up the $2^{\text {nd }}$ Irish commando. ${ }^{33}$ The name of the Russian war correspondent who became a Boer general, Colonel Yevgeny Maximov, rounds off Davitt's impressive list of contacts. ${ }^{34}$ 
Of the Irish commando leaders, Davitt met John MacBride and John Blake of the $1^{\text {st }}$ Irish Transvaal Brigade, as well as Arthur Lynch and Thomas Oates of the $2^{\text {nd }}$ Brigade. Davitt liked the educated, urbane and somewhat mercurial Lynch, stating that the Irish-Australian was, "[t]all, soldierly looking \& much more presentable than either Blake or MacBride. Is much smarter also in other respects. Appears to be welleducated. Gentlemanly young fellow." ${ }^{35}$ In turn, Lynch thought Davitt something of a Spanish hidalgo.

More intriguing, however, was Davitt's liaison with a French soldier in the Boer army, Colonel De Villebois-Mareuil. The two men met when Davitt was not very far from the front line in the Orange Free State. A few years after Davitt's death, their involvement in an unlikely conspiracy was mooted by one of Davitt's journalist acquaintances, the eccentric and adversarial Patrick Dermot Kenny from Mayo, writing in the Saturday Review simply under the single name 'Pat'. Backed by funding from William Randolph Hearst, the American newspaper tycoon, Davitt wanted "to bring the war into Europe", ${ }^{36}$ Kenny claimed. Kenny also made the incredible claim that Davitt had raised a force of 70000 French army reserves to go to South Africa to fight under Villebois-Mareuil. However, the French officer refused to become involved in the matter and, in any case, died on 5 April 1900, when Davitt was still in Africa, possibly due to suicide, Kenny suggested. Another layer of complication in the conspiracy, Kenny claimed, was that Davitt believed that the Royal Navy would intervene to stop this French army sailing to Lourenço Marques, leading to war between France and Britain. ${ }^{37}$ This accusation has to be treated with caution as there is nothing to substantiate what Kenny wrote, and he was by this time beginning to ingratiate himself with Irish unionism. However, it is clear that Baron Van Dedem had some part in the French colonel's scheming to establish an international corps. ${ }^{38}$ The nearest that Davitt got to actually seeing any military action in South Africa, though, was when he stood on a koppie looking down at the awesome sight of the vast British army camp outside Bloemfontein.

During his short time in South Africa, Davitt travelled a considerable distance: in all, over 2000 kilometres, the equivalent of four times the length of Ireland. The photograph used as the frontispiece of Davitt's South African war book shows him sitting on a pony or a mule. As Davitt had lost an arm in a factory accident when young, he was not used to regular horse riding. This must have been a wearying task for him, but in the southern Free State, the only way to move about was on horseback or on foot. Davitt clearly tackled the challenge well and without complaint. ${ }^{39}$

Not far off, at Kroonstad, Davitt was laughingly told by General Smuts that the Irish brigade had been badly cut up when caught by the English nearby, while "engaged at the time in emptying bottles at some hotel or drink store. This Brigade's weakness. If story true, it will be a great disgrace to Irish name." ${ }^{40}$

To the Irish parliamentarian, John Dillon, Davitt confided that some Irish did not join the Irish commandos, "but have the good sense to remain with their Boer officers". ${ }^{41}$ Major MacBride, who was always quick to refute any slur on the 
good name of the Irish Transvaal Brigade, later strongly denied the accusation of drunkenness at Brandfort. Similarly, Ernest Luther's diary of his time with the Irish commando confirms that the unit fought hard and well. ${ }^{42}$

Writing to John Dillon on 4 April from the Grand Hotel in Pretoria, Davitt commented in a frank manner:

I have had and am still having a most interesting time and am pleased to say my health is completely restored after this long voyage and this thrilling experience of the past fortnight. Make no mistake about it this war has scarcely yet begun ... I saw Major MacBride on way here. There has been a "split" of course. That is inevitable in every Irish concern, military or civil. Colonel Blake is, I am told fond of the bottle, and it is alleged that McBride keeps him good company. Arthur Lynch of Paris, who O'Kelly knows, and a man named Oates from Roscommon broke away from Blake and founded "the $2^{\text {nd }}$ Irish Brigade. ${ }^{43}$

From Pretoria, Davitt moved 58 kilometres to Johannesburg, which he found a ghost town, its population reduced from 120000 to 20000 as a result of the exodus of pro-British inhabitants to the Cape Colony and Natal. Some of their homes had since been occupied by Orange Free State refugees. Davitt referred to the absent inhabitants of the suburban villas as "upstarts who have got more wealth than they ever dreamt of in their pre-Rand days". Davitt noted approvingly how a police guard had been placed at the deserted home of the former British representative William Conyngham Greene, who also happened to be an Irishman, a nephew of the archbishop of Dublin. ${ }^{44}$

It was in Johannesburg that Davitt met some members of the $1^{\text {st }}$ Irish Transvaal Brigade, including MacBride and Blake (the latter would shortly afterwards desert his Irish commando for a Boer-led one), and the easy-going Captain Oates, with whose family he had tea and heard about the death of their son, Tommy, killed with the Irish unit outside Ladysmith. Davitt pestered MacBride for war mementoes, which could be auctioned back home for the Irish nationalist cause at a national bazaar. He was given a British shell and a Mauser rifle, both of which appear to have been confiscated later at the Komatipoort border with Mozambique by the Portuguese authorities. ${ }^{45}$

Davitt did not visit the camp of the much larger $1^{\text {st }}$ Irish commando even though MacBride made arrangements for him to meet the commando when it was in northern Natal. ${ }^{46}$ It is not clear why Davitt never showed up. Maybe Davitt was not after all so enamoured of Foxy Jack, as MacBride became known. In any case, the commando was soon to leave Natal as Ladysmith had fallen to the British and morale was low. Many Irish brigadiers had filtered back to the Rand and were scattered between Johannesburg and Pretoria, some later that May regrouping in the Orange Free State under De la Rey for the long retreat to the Vaal River. ${ }^{47}$ They were joined by 58 Irish Americans who had come out to fight under the guise of being an ambulance corps. 
Davitt thought very highly of this outfit.

After Blake and MacBride's fighters had left Natal, Davitt visited Lynch's $2^{\text {nd }}$ Irish commando at Glencoe in northern Natal, near the battle site of Talana (20 October 1899) where Irish had fought for both the Boers and the British. The Irish camp at Glencoe ${ }^{48}$ was well equipped, perhaps too much so (stories of plundering and theft circulated). Davitt lectured Lynch on the evils of Parnell, "a cold-blooded sensualist". ${ }^{49}$

Davitt had wanted to sail for home from Lourenço Marques on 9 May. On Friday, 4 May, the day before the British army resumed its advance into the Orange Free State, Davitt was panicking because he had "not obtained anything like information I require for the book ... Another fortnight absolutely necessary and have made up my mind to stay that much longer." 50 The following day, General Smuts told Davitt that the British "came across [the] veld in overwhelming numbers \& could not be stopped". ${ }^{1}$ Not surprisingly, Davitt remained only another 10 days in the dying republic. On Monday, 7 May, he attended the last sitting of the South African Republic's volksraad, "a funeral ceremony over the body of what would soon be a slain Republic". Davitt continued, "[ $\mathrm{t}]$ he assembly of the rand resembled a gathering of Wesleyan ministers." ${ }_{52}$

Having stirred the British pot as much as possible by his visit 'behind enemy lines' and while still in the Transvaal, Davitt suddenly began to have qualms about the consequences of his actions. What would happen to him once he set foot on British soil? He asked Dillon's advice, fearing he would face "trumped up charges". ${ }^{3}$ He enquired how his visit had been received in the press, adding that he had been careful about what he said but was worried what spin the jingoes would put on it. He wondered about going to Paris and then on to America for a few years. This fear was not without merit. Arthur Lynch later experienced a full-blown trial for treason, a capital offence, when he ventured to Britain from safety in France after being elected in his absence as MP for Galway in 1901. Unlike Lynch, Davitt, of course, had not been a belligerent, but he had most certainly given succour to the monarch's enemies in time of war and had no wish to either repeat his long years in prison or overly moderate his provocative political stance.

In his 1908 article about Davitt in the Saturday Review, Kenny commented that, after conspiring with Villebois-Mareuil, Davitt found out that the British secret service had a dossier on his activities, "and he expected to be thrown into prison for the rest of his life; but with the fine stolidity of British Toryism the Government let him go home". ${ }^{54}$ Kenny also claimed that after Arthur Lynch had gained a death-sentence reprieve, it was Davitt's intervention, which resulted in King Edward VII granting Lynch a pardon in 1907. All of this was highly unlikely and not surprisingly denied by Lynch.

In the end, Davitt took the risk of returning to Ireland. On 15 May, the day he left the Transvaal, he wrote: 
Farewell Pretoria! You will soon cease to be [the] capital of a nation. The enemy will make you another of his 'centres of civilisation'. Brothels, paupers, hypocrites, gospel mongers in the pay of British mammon, and all the other unseparable accompaniements of Anglo-Saxon progress will replace the kind of life you have been familiar with; not a perfect life, not a blameless one, but one infinitely better, cleaner, and more truly civilised than one which will begin here the day the ensign of England will float once more over a defeated Nationality. ${ }^{55}$

Davitt arrived at Lourenço Marques on 16 May 1900 and waited five days for his ship, the 2 500-ton Bundesrath, to sail. Of the ship, he drily wrote that she looked a dirty and uncomfortable boat. He left Delagoa Bay (Maputo) on 21 May, just over eight weeks after he had arrived in Southern Africa. By then, the Transvaal republic was doomed. Ten days later, Johannesburg would be occupied by the British, MacBride's men being among the last to evacuate the mining town. Pretoria fell without resistance on 5 June 1900. Yet, even with disaster looming, the Transvaal's detective division took care to investigate reports that there was a risk of an attack on Davitt in Lourenço Marques by the "English crowd". ${ }^{56}$ Nothing materialised, and Davitt was wined and dined there by Mr and Mrs Hollis, the United States consul and his wife.

Davitt disembarked at Marseilles on 25 June and was in Paris the following day. He arrived in London on 30 June, where he wanted to meet Dillon - at Davitt's specific request anywhere outside of the Palace of Westminster. Possibly because Davitt feared arrest, he planned only one night at the Euston Hotel before returning to Ireland, "as I am anxious to get home and to set to work on a book I am planning as a result of my visit to South Africa". ${ }^{57}$ He was in Dublin on 1 July 1900, "About on tour some 120 days". 58

\section{Part 2: Davitt's mind-set and the consequences of his visit}

\section{Mind-set}

Davitt's health had not been good prior to departure for Africa. How much of that was psychosomatic is difficult to tell, but certainly one can discern a distinct change in temperament in his diary and letters as his African adventure progressed. And that was undoubtedly because he regarded the trip as an adventure and a release from the straitjacket of his recent parliamentary existence. The Anglo-Boer War was the breaking point, which led to his resignation from the House of Commons. The initial entries in Davitt's diary on the voyage are more personal and nearly self-pitying at times than later diary comments, when he was feted on the Highveld by the ruling Afrikaner establishment and intent in collecting copy for his book.

Davitt's South African diaries highlight his general demeanour and outlook towards life. He did not, for example, forget wrongs either against him personally or 
against Ireland. He regularly noted national anniversaries in a somewhat ritualistic manner. These included St Patrick's Day (17 March) as well as the now relatively obscure date of the birthday of Robert Emmet (4 March), the leader of the 1803 Irish nationalist insurrection in Dublin. ${ }^{59}$ Deeper emotionally for Davitt was the day he was released from a term of penal servitude in Dartmoor, and the anniversary of the loss of his arm (8 May). Of his birthday and feeling his age (he was 54 years old), Davitt observed -

What 'a time' I have had during these [42] long years? Ah, well, had I been killed instead of being maimed I should have missed many blessings \& [?] My life has not been near as miserable as many who did not lose an arm as who were strangers to the 'sweet uses' of adversity. ${ }^{60}$

On 14 May, Davitt noted the anniversary of the day he had been arrested in 1870 , with the words -

Thirty years have flown by since then, nine of these having been passed in H. Majesty's prisons. Wonder whether I have suffered more in mind at any rate during the time which has elapsed since. ${ }^{61}$

These were all deep waters, which told their tale of the man whose life had ebbed and flowed with the competing pull of Irish parliamentary politics and advanced Irish nationalism, including its physical force tradition. Then there were the occasional outburst of prejudice, not least racial. This is strange, given Davitt's fervent denunciation of the persecution of Jews in Russia, although for him, as for the Boers in South Africa, the key element there was opposition to an imperial power. And mixed up with this mid-paranoia, there was semi-fantasy. He fancied there were British spies on board the Oxus. The strange and exotic characters on board certainly fascinated him. Of one woman, he asserted:

Delightful! Good for my comedy!! Rumoured at breakfast today that "Lady Madagascar" (our dark beauty) is the wife of - a Negro!! Is this the Jews revenge? And now it is being circulated and the Baron [Van Dedem] \& others are disposed to credit the story. Possibly her husband may be a halfcaste but in any case whether a full or a half breed native is her husband she is now looked upon as a lady capable of marrying a man of colour for his money! How like this bigger Society on land this little circle of a hundred people is! The same pretensions, prejudices, passions, jealousies, revenges! [14 March]

Davitt had "a very poor opinion" of the French military enclave of Djibouti, hinting at xenophobic if not racial undertones. ${ }^{62}$ Laurence Marley criticised Davitt for ignoring the plight of the African population in the Boer republics: 
Davitt's attitude to the South African natives was clearly not consistent with a crusade for international justice and liberty ... he seemed, however, to have had no ethical qualms about his investments, not even in South Africa. Of course, he essentially ignored the abject working conditions of black miners in Johannesburg, and in this he was hypocritical. ${ }^{63}$

Davitt was certainly enamoured of the image he had conceived of the Boers. He praised the "morality \& sobriety" of the young Boers and asserted, "[n]ot a single woman of ill-fame [is] known to be in Brandfort [battle front-line]." ${ }^{64}$ Did this blind him to the plight of the African population? Davitt did state that he believed the African population was treated worse by the British than by the Afrikaners in South Africa. In one aside in his diary, Davitt wrote partly admiringly, partly patronisingly of the Africans in the Transvaal who operated the semaphore control boxes on the railways, "who appear highly intelligent \& were capable of this responsible work ... No accidents occur owing to effective management and to admirable upkeep of [the] permanent way." ${ }_{65}$ But the fundamental reality was that Davitt, like most Irish nationalist politicians of his time, did not consider race an issue and swept aside any such complication to their view of the war's two and key protagonist groupings in their Irish pro-Boer agitation. This is emphasised by Davitt's uncritical acceptance of what he was told by the Boers. It also emerges in Davitt's notebooks, letters and the book which he later published. A case in point regards forced labour:

Saw a native commando - that is about a hundred Natives commandeered for the working of farms while the Boers are fighting. Some of them brought from distances of a hundred miles. They come willingly \& make no complaint. They are not entitled to wages under the law but they are all paid. $\mathrm{Mr}$ Crotsee [Coetzer] says that the fullest reliance can be placed in their integrity. The Transvaal Govt had an offer of ten thousand men from the Swazi chief for use against the English. The offer was of course refused. ${ }^{66}$

In this regard, Davitt was typical, too, of his age and class. Other prominent Irish politicians who visited South Africa in the period were Swift MacNeill (1887), John Redmond (1894), Colonel Edward Sanderson (1897/1898) and Arthur Griffith (1897/1898). None of them expressed any genuine sympathy for the plight of the African population yet spoke loftily of freedom and the rights of peoples. It has to be added that the same was still true of the official Dáil Éireann delegation of Colonel Maurice Moore and Patrick J Little, which visited South Africa in 1921, eight years after the founding of the South African Native National Convention, the forerunner of the African National Congress. ${ }^{67}$ Nor should it be forgotten that Davitt's political confidant, John Dillon, had asserted that Ireland deserved self-government, "because we are White men". ${ }^{6}$ 
Like many a contemporary academic on the conference circuit, Davitt expressed no curiosity about the landscape of the two countries he visited or the subtleties or nuances of the places through which he passed. He saw large parts of the Eastern Transvaal (Mpumalanga), the Orange Free State (Free State) as far south as Brandfort, the Witwatersrand (Gauteng) and northern Natal (KwaZulu-Natal). Yet, there is practically nothing in his diaries or letters about the countryside, even though some of this is very striking. There is only the aside, "[e]ucalyptus seems to be planted everywhere there are people from Lourenco Marques to Pretoria" ${ }^{69} \mathrm{He}$ also displayed a remarkable ignorance about matters on which he might have been expected to have read up. He talks of passing Bronkhorstspruit on the train and seeing the trees, which marked the site where the defeated British soldiers were buried in December 1880 , yet clearly did not know that those soldiers were, in fact, Irish. ${ }^{70}$ He reacts with astonishment when he learns about the dorp (village) of Belfast on the railway line that "A Mr O'Neill [O'Neil] is the founder of the town!"'11 Later he was to hear also of the Emmets (spelt 'Emmett' in South Africa) who were linked through marriage to General Louis Botha.

Similarly, when Davitt saw 400 British prisoners of war he did not initially realise that within their ranks were many Irishmen. In total, around 2000 soldiers in Irish regiments in the British army were classified during the war as 'Missing and Prisoners', more than $90 \%$ of whom were members of the Royal Irish Rifles (685), the Royal Irish Fusiliers (578) and the $13^{\text {th }}$ Battalion (Irish) Imperial Yeomanry (461). ${ }^{72}$ Davitt's comment was:

I cannot well describe this feeling which this scene created in my mind. A personal sympathy towards them as prisoners. A political feeling that the enemies of Ireland and of nationality was humiliated before me and that I stood in one of the few places in the world in which the power of England was weak, helpless \& despised.

Davitt said how well treated the British prisoners were. This was in contrast to the $\left(5^{\text {th }}\right)$ Lancers, whom Davitt does not seem to have known were Irish, and about whom he wrote that they killed captured Boer prisoners, presumably at the battle of Elandslaagte. He prudishly denounced the insulting sketches made by British prisoners on the walls of the Model School in Pretoria where the officers were accommodated, with "servants provided". ${ }^{73}$ Later when Davitt did realise that some of these prisoners were Royal Irish Fusiliers, he postulated in his diary the ridiculous notion that the Anglo-Irish Lord Roberts "is allowing these men to be captured as a ruse". ${ }^{44}$ This was something of a play on the contemporary feeling in Irish nationalist circles that Irish troops in the British army were being used in South Africa as cannon fodder. ${ }^{75}$

Conversely, Davitt had a somewhat blinkered vision when it came to his admiration for the Afrikaner people (the men resolute and noble, and women tenacious and virtuous), which might have been part of a reaction against the complications within 
his own mind about on which side of the nationalist fence he belonged in Ireland. He revelled in what he saw as a fundamentally simple African conflict and raged at the contrast with Ireland, "Heavens how paltry we look as fighters for Nationality alongside these few people." " Another such example was Davitt's note in his diary for 4 May 1900, recalling Transvaal Vice-President Schalk Burger addressing parliament in Pretoria:

Speech well delivered without pause or hesitation. Marked by solemn utterances $\&$ listened to breathlessly. After a few minutes there was occasional applause but nothing like what an Irish gallery would be inclined to do. We wd cheer, the Boer will fight. ${ }^{77}$

Some reports state that Davitt was depressed when he left the Transvaal. A Baptist cleric, Rev. HJ Batts, even reported to Lord Roberts that he had met Davitt on the Pretoria railway station the day he departed from the Transvaal and that the Irish politician had said to him, "I go away broken and sick at heart, thoroughly disappointed. I would give $£ 100$ to withdraw what I have written." 78 The fact, however, that there was no platform party for Davitt's departure, unlike his arrival, is in itself interesting. With the sound of enemy gunfire already not far from the Vaal River, the Boers had drawn in on themselves in the conflict. This was not Davitt's world and he must have realised his exclusion.

\section{Consequences}

Carla King, in her biography of Davitt's later life, makes several observations on Davitt's African sojourn: that for a time the Anglo-Boer War pushed Davitt "away from mainstream liberalism and in the direction of more uncompromising nationalism" 79 ; that the war "increased Davitt's disillusionment with the British Liberal Party"; and that "politically in Ireland he [Davitt] had nowhere to go". ${ }^{80}$ Yet, beyond this reality, and prompted by circumstances and alienated from former allies, Davitt had found somewhere to go politically. His South African experience had accentuated the internationalist within him after what he described to Dillon on 25 April 1900 as "the most interesting experience of my whole life". No matter how wobbly the logic of Davitt's espousal of the Boer cause, it was genuinely felt. Not unlike Arthur Griffith, who had also ventured into the Boer republics, Davitt saw these states as both a lesson to Ireland as well as an anti-imperialist cause that Ireland should espouse. Observing the two Boer republics in their life-and-death struggle opened up new horizons and possibilities for Davitt, intensifying the political questions he was already pondering. The trajectory of that political thinking, intensified by the South African sojourn, assisted in Davitt emerging in the final phase of his life beyond the confines of Irish nationalism as the radical and anti-imperial internationalist. That this persona never fully matured was the misfortune of death rather than inclination. The publication of Davitt's The fall of feudalism in Ireland in 1904 was in a sense his apologia for an outlook, which he was beginning to change in his drive against imperialism. This, 
coupled with his interest in land reform, women's rights and opposing anti-Semitism, attracts Davitt to the modern scholar.

South Africa certainly gave Davitt a renewed desire to travel and in the coming years, he was to visit Russia twice. But pragmatically, any discussion of the impact and legacy of Davitt's South African journey must keep in mind that he lived only five more years, dying on 30 May 1906, one day short of the fourth anniversary of the signing of the Peace of Vereeniging. There is therefore no personal, long-term impact of his South African adventure to consider.

\section{Irish nationalism}

There was, however, a long-term legacy for the Ireland-South Africa experience of which Davitt was a key part. The nexus would continue for several decades after Davitt's death and would include former Irish commando members fighting in the 1916 Easter Rising in Dublin as well as the later phenomenon of the "Fellowship of disaffection" forged between South Africa and the Irish Free State to undermine the British dominion system. ${ }^{81}$ But there were immediate consequences too. Even when 10000 kilometres away, Davitt still found himself tangentially involved in another Irish split at home following his resigning of his South Mayo seat. Into Mayo came the advanced nationalists in the guise of Arthur Griffith and Maud Gonne, supported by the maverick politician Tim Healy, to nominate the war hero still fighting in South Africa, Major MacBride, for the vacant seat. However, the equally maverick Irish parliamentarian and newspaper editor, William O'Brien, was not going to tolerate anyone, especially Healy, invading what he regarded as his own domain. Besides, O'Brien was not enthused by "the all but delirious enthusiasm in the Boer cause which was then convulsing Ireland". 82

The result was that the organisational wing of the Irish Parliamentary Party, the United Irish League, fielded a relatively unknown political figure, John O'Donnell, who was in prison for his political activity, being only released shortly before polling day. In a small poll, O'Donnell defeated the African freedom fighter by 2401 votes to 427. This was a remarkable commentary in itself on the complexities of advanced nationalist politics. ${ }^{83}$ In November 1901, Griffith's paper, the United Irishman, claimed that in South Africa, Davitt had "haunted Major John MacBride's hotel, imploring him to accept a seat in the British parliament". ${ }^{84}$ This seems highly unlikely given the South Mayo debacle. ${ }^{85}$ The two only met once, and Davitt did not appear at a follow-up meeting, which had been arranged.

Despite this setback for the Irish pro-Boer movement, Davitt's South African sojourn gave a new impetus to the movement which, despite increasing military reversals for the Boers, survived well into the Irish summer of 1900. And in May 1902, the month the war finally concluded, a further reminder of the Irish-Boer nexus came with the publication of Davitt's epic book, The Boer fight for freedom, published by Funk and Wagnalls Company of New York. Davitt's notebooks show he had a list of some 17 possible titles, including Wilful murder of a nation, The Boer at bay, 
Imperial burglary, The game of the century, The jingo war, The killing of a nation, and For land en volk! The book was dedicated to the memory of General Philip Botha. It was a hefty 603 pages in length with 111 illustrations and seven maps. A "[t]hird edition, revised and completed" (also dated May 1902) was produced with an extra four pages and an elaborate embossed cover featuring a coloured Vierkleur (Transvaal flag) on the spine. A second edition has yet to be discovered and may never have been produced.

Davitt's initial purpose for travelling to the war zone had been to collect material for a book, which would make him some money; however, to give him his due, at the same time promoting a cause in which he believed. In the event, his book had to compete with an extraordinary large number of war reminiscences, a great many written by journalists. ${ }^{86}$ The book is something of a hotchpotch, part factual and thematic narrative and - as Davitt's biographer, TW Moody, commented to the author in 1978 - part potboiler. Yet, it is a strangely detached book and certainly a very valuable source for a study of the war and of the foreign units in the Boer army. It was, however, something of a publishing failure. For example, only 250 copies were ordered in South Africa. To John Dillon, Davitt lamented, “Alas for my poor book! De Wet's book is already in the hands of a London publisher and Botha and De La Rey have another in preparation!!'"87

Soon Davitt reported that he had heard Mrs De la Rey was writing a book and that De Wet had been offered $£ 100000$ for his volume. ${ }^{88}$ Such grumbles apart, Davitt's own book is one of the key contemporary texts on the war that is hostile to the British side. The year after the Boer fight for freedom had appeared, following a Hearstpaid journey to investigate the Kishinev pogrom, Davitt would publish a volume on anti-Semitism in Russia, entitled Within the Pale: The true story of anti-Semitic persecutions in Russia, reinforcing his trajectory as an internationalist in the cause of subjected peoples. ${ }^{89}$

During his South African trip, Davitt was interviewed by the Boers' progovernment newspaper Die Volksstem. This ceased publication on 4 June 1900, having been printed for a while on the Boer frontline at Glencoe, Natal. But Davitt himself also wrote of his experiences for the press. There were well over 300 war correspondents covering the Anglo-Boer War on the ground, the first modern war field press corps. ${ }^{90}$ Some of these were Irish. Arthur Lynch used journalism as a cover to get to the Transvaal to fight, in the same way an Irish-American contingent used an ambulance corps as their front. But can Davitt legitimately be classified as one of these journalists?

On departure for Africa, Davitt had already arranged to write some war pieces for the Freeman's Journal. He had already started his trip when his commission for the New York Journal was finally confirmed. These assignments were a useful financial supplement but, in fairness to him, he did not pretend that he went to Africa under the banner of a fully-fledged war correspondent. From the start, he was unapologetically partisan. His letters to Ireland for publication in the Freeman's Journal appeared in 
nine issues between 6 and 30 June 1900. These opinion pieces had the tone of the 'I was there' foreign correspondent, though in fact much of Davitt's information was second-hand, making his on-the-spot accounts less valuable as a source than the retrospective articles written by Arthur Lynch for Revue de Paris in 1900 and the - albeit heavily edited - articles by John MacBride for the Freeman's Journal in 1906/1907.91

\section{The Boer republics}

The arrival in Pretoria of a high-profile figure gave an additional publicity boost to the republics. The fact that Davitt gained individual audiences with the senior politicians and generals indicates the status of the visitor. But there was a distinct element of surprise at the arrival of this strange guest. While the circumstances were different, there is the feel around Davitt's visit of one of those high-profile and rather naïve visitors to Nazi Germany during the 1930s. But whatever his reception, the visit of Davitt to the Boer republics came too late. Had he arrived during Black Week (December 1899), the impact abroad of his visit would have been greater and, indeed, the possibility of action by the British authorities back in Dublin against Davitt on his return more probable. Davitt might have written home to Dillon in April 1900, "This war is scarcely yet begun". ${ }^{92} \mathrm{He}$ was not referring to any future guerrilla war that was to emerge. He was, in fact, experiencing the final phase of the formal conflict, which, over the period he was in the republics, shifted dramatically as the British military advance recommenced. By early June, this would result in the annexation of both Boer republics.

Naïve as Davitt might have been in his approach, and his ignorance must have been obvious to the Boer leadership; nonetheless, there is no doubt but that they respected him and also realised the standing of the man who had come into their midst. And on the very practical level, they paid his hotel bill, which must have been a great relief for the cash-strapped Davitt. Various financial requests totalled about $£ 99-4-00$ were made by the proprietor, Mr S Schlomer, to cover Davitt's expenses at the Grand. ${ }^{93}$ The Grand Hotel was described as follows:

It was one of the finest hotels in South Africa, comparing favourably with its European contemporaries. It had accommodation for 70 visitors and boasted 30 white servants and 23 coloured attendants. ${ }^{94}$

Davitt clearly had no concerns about being compromised by accepting accommodation from the Transvaal government and did not skimp on his expenses.

Perhaps the most significant outcome of Davitt's trip was the dramatic political fall-out relating to his receiving by chance a confidential British report entitled Military notes on the Dutch Republics of South Africa. Compiled in Section B, Intelligence Division, War Office. ${ }^{95}$ This was an analysis by British Military Intelligence of the Boer republics and their military capacity and was issued in April 1898 to a select few 
in the military, government and the British civil service, with a revised edition printed in June 1899. A copy of this printed secret report had been picked up by the Boer forces at Dundee among the papers of General Sir Penn Symons, following his death from wounds sustained in battle.

The document or a copy fell into Davitt's hands who sent it to an American newspaper and from there it was seized upon by the British press, making it public knowledge for the first time. This embarrassing revelation gave the lie to the British establishment's claim that it had been ignorant of the strength of the Boer army prior to the outbreak of war. To bleed the matter to its full extent, Davitt himself quoted the opening section of the Military notes in his own Boer fight for freedom. All this played into the hands of the Boers. The initial British setbacks in late 1899 had been blamed by the British establishment on British Military Intelligence and particularly its director, the Waterford-born, Major General John Ardagh. But when it emerged that Military notes had already been in the hands of the British army and War Office in 1898, Ardagh was vindicated and the Boers' resistance further enhanced. ${ }^{96}$

\section{Back home}

Back in Ireland, Davitt would hotly dispute what Rev. Batts had claimed about him being disillusioned with the Boers. But clearly, Davitt had said something negative about the Boer situation, even if Batts exaggerated and twisted his report of their conversation. Later, Patrick Kenny would claim that on his return to Ireland, Davitt told him, "his last enterprise against the Empire ... was the biggest blunder of his life". ${ }^{97}$ But the truth is that we do not really know what Davitt actually thought by then. This in itself is curious for someone who wrote so prolifically. Kenny also asserted that Davitt had said to him, "[m]y diaries are not to be published as such, and in no instance without my wife's permission." 98 Following the revealing personal insights recorded during the voyage, these South African diaries became essentially notes for his book rather than private musings or observations on people and events. Davitt followed the Irish nationalist 'party line' in his enthusiasm for the Boer cause. However, the Boers regarded the Irish in their army with a mixture of curiosity, amusement, bewilderment and, it has to be said, caution. Perhaps Davitt picked up on this.

Davitt's flirtation with a later scheme by Baron Van Dedem to establish a new European continental news agency was a product of his trip to South Africa but not in itself linked to Africa. ${ }^{99}$ In any case, it came to nothing. What was directly associated with his trip was the unseemly jockeying for the unofficial role of representing nationalist Ireland when the exiled leader from the doomed republic reached Europe. Davitt was closely involved in the welcome to Europe of former President Kruger and the presentation of an Irish address of sympathy to the old man. But matters went further than that. It is clear that Davitt was regarded by the Boer leaders as providing a conduit to Irish nationalists for those Boers in exile and the Boer generals who visited Europe in the summer of 1902. 
Jostling for status with the Boer exiles in competition with Davitt was the poet Yeats' muse and advanced Irish nationalist activist, Maud Gonne. She now had in tow Major MacBride of the former Irish Transvaal Brigade. Another actor in this saga was the former parliamentary party MP Frank Hugh O'Donnell, who had been in effect a Boer spy in Ireland during the war. ${ }^{100}$ The Gonne-MacBride camp had not forgotten how Davitt had not opposed John O'Donnell, "the rejected constabulary-man"101 in the Mayo South February 1900 by-election, and it was said, "Davitt went down in the estimation of secret society men and they shunned him in Dublin." ${ }^{102}$ Davitt however trumped Maud Gonne, being dined by the astute Boer leadership who knew full well who could best represent their case back in Ireland.

Davitt admired the Boers and, in turn, the former Boer leadership liked and respected him, more so it has to be said than they did the Griffith-Gonne camp, about whom they had been warned by Frank Hugh O'Donnell during the war. As a man who prized loyalty, Davitt for his part never wavered in speaking out for the Boer cause. For instance, on 8 June 1902, he was the star turn at the unveiling of a sevenmetre-high memorial in Armagh to the 32-year-old Gaelic footballer, Hugh Carberry, an Irish brigadier who was shot in the head at the battle of Rietfontein (24 October 1899) near the Irish commando camp outside Ladysmith, subsequently dying of a stroke in the Boer capital, Pretoria, three months later. The report by the Royal Irish Constabulary (RIC) commented that, at the ceremony, Davitt:

Delivered a characteristic speech defaming the British soldier and eulogizing the Boers. Sedition was freely indulged in, but as the Police note taker was ejected from the meeting, evidence of the language used was not available. ${ }^{103}$

Dublin Castle believed that at this time, the Boers gave Davitt at least $£ 12000$, which he passed on to the Irish Republican Brotherhood (IRB). This may well be correct. We also know that during the war, the Boer envoy extraordinary and minister plenipotentiary in Europe, Dr WJ Leyds, had been siphoning funds to the IRB, probably through Frank Hugh O'Donnell. ${ }^{104}$ Interestingly, in 1896, Leyds had refused permission to Davitt to publish an account of an interview he had had with the diplomat.

Davitt's attitude and mind-set regarding the Boers are well captured in a note he wrote from The Hague to John Dillon a couple of months after the Carberry Armagh rally. Davitt enthused:

You will feel some little human envy, I am sure, when I tell you I spent most of last evening with De Wet and Delarey 'who fought their battles o'er again' amidst clouds of tobacco smoke. It was one of the most delightful evenings I have ever had. ${ }^{105}$ 


\section{Endnotes}

${ }^{1}$ This work is in part based upon research sponsored by the National Research

Foundation of South Africa and the University of KwaZulu-Natal. Any opinion, findings and conclusions or recommendations expressed in this material are those of the author and therefore the National Research Foundation does not accept any liability in respect thereto.

${ }^{2}$ Davitt's articles in the Freeman's Journal were published on 6, 8, 11, 16, 19, 23, 26, 28 and 30 June 1900.

${ }^{3}$ TW Moody. Davitt and the Irish revolution, 1846-8. Cambridge: Clarendon Press, 1982.

${ }^{4}$ L Marley. Michael Davitt: Freelance radical and frondeur. Dublin: University College Dublin Press, 2007/2010; C King. Michael Davitt after the land league. Dublin: University College Press, 2016. Other modern studies of Davitt include that of J Devoy. Michael Davitt. Dublin: University College Dublin, 2008; F Lane \& AG Newby (eds). Michael Davitt new perspectives. Dublin: Irish Academic Press, 2009.

${ }^{5} \mathrm{C}$ King. "The Madhi for an Irish constituency or at least a seat in Dublin town council: Davitt and Africa". History Ireland 14/4. 2006. 10-11; JG MacNeill Swift. What I have seen and heard. London: Arrowsmith, 1925, chapter 5.

${ }^{6}$ National Library of Ireland. File: Ms 19 933, Irish Transvaal Committee minute book, 1899. DP McCracken. The Irish pro-Boers, 1877-1902. Johannesburg, Perskor, 1989, revised edition as Forgotten protest: Ireland and the AngloBoer War. Belfast: Ulster Historical Foundation, 2003.

${ }^{7}$ MA Leeson. Reminiscences of the Franco-Irish Ambulance; or our "Corps' with the Mocquarts and on the Loire 1870-1871. Dublin: McGlashan \& Gill, 1873.

${ }^{8}$ Royal Commission on the War in South Africa. Appendices to the minutes of evidence. Cd. 1792. London: HMSO, 1903, 21-40; K Jeffery. "The Irish soldier and the Boer War". In J Gooch (ed), The Boer War: Direction, experience and image. London: Routledge, 2013, chapter 8.

${ }^{9}$ R Richard. "The Irish Transvaal Brigades". Irish Sword, 11/45. Winter 1974. 201-211.

${ }^{10} \mathrm{DH}$ Akenson. Occasional papers on the Irish in South Africa. Grahamstown: Institute for Economic and Social Research, 1991; DP McCracken (ed). The Irish in southern Africa as volume 2 of Southern African-Irish studies. Durban: ISAP, 1992; C van Onselen. Masked raiders: Irish banditry in southern Africa. Cape Town: Jonathan Ball, 2010.

${ }^{11}$ PA McCracken. "Arthur Griffith's South African sabbatical" and "The quest for the Middelburg Courant". In Southern African-Irish Studies 3. 1996. 227262 and 282-289; The Nation. 13 July 1897.

${ }^{12}$ Le Petit Journal. 31 December 1899.

${ }^{13}$ BM Walker. Parliamentary election results in Ireland, 1801-1922. Dublin: Royal Irish Academy, 1978, 414.

${ }^{14}$ Freeman's Journal. 2 October 1899.

${ }^{15}$ Hansard (House of Commons). 17 October 1899. Vol. 77, cols 128-9.

${ }^{16}$ JV Morley. Recollections. London: Macmillan, 1917, vol. 1, 340, 372. 
${ }^{17}$ Hansard (House of Commons). 25 October 1899. Vol. 77, cols 614-22.

${ }^{18}$ M Davitt. The Boer fight for freedom. New York: Funk \& Wagnalls, 1902.

${ }^{19}$ GA Lyons. Some recollections of Griffith and his times. London: Talbot, 1923, 35.

${ }^{20}$ National Archives, London. Colonial Office (Irish Office) CO903/8, Irish Crimes Record, n.d.

${ }^{21}$ National Library of Ireland (NLI). O’Brien papers, Michael Davitt to William O’Brien, 11 January and 14 February 1900.

${ }^{22}$ A fuller narrative of Davitt's visit to South Africa can be found in DP McCracken. MacBride's Brigade: Irish commandos in the Anglo-Boer War. Dublin: Four Courts Press, 1998, 89-95. See also Marley op. cit., pp. 247-257.

${ }^{23}$ National Archives of Ireland. File: Crime Branch Special, 'S' series, box 17, S/21342, 12 March 1900.

${ }^{24}$ JJ Auchmuty. Lecky. Dublin: Hodges, Figgis/Longmans, 1945, 25.

${ }^{25}$ King Michael Davitt ... op. cit., p. 476.

${ }^{26}$ Trinity College Dublin (TCD). Davitt papers. File: Ms 9573, 24 March 1900.

${ }^{27}$ A photograph of Blake on the balcony of the Grand Hotel appears in the earl of

Rosslyn's Twice captured: A record of adventure during the Boer War. Edinburgh: William Blackwood, 1900, 389-392.

${ }^{28}$ Adapted from McCracken, MacBride's Brigade ... op. cit., pp. 91-92.

${ }^{29}$ M Davitt. op. cit., p. 301.

${ }^{30}$ TCD. Davitt papers. File: Ms 1803, Davitt to John Dillon, 4 April 1900.

${ }^{31}$ A curious feature of John Blake's book $A$ West Pointer with the Boers. Boston:

Angel Guardian Press, 1903, is the number of photographs of young Afrikaner women scattered throughout the volume.

32 TCD. Davitt papers. File 9592, 15 May 1900.

${ }^{33}$ DP McCracken. "From Paris to Paris, via Pretoria: Arthur Lynch at war". Études Irlandaises 28/1.2003. 128.

${ }^{34}$ A Davidson \& I Filatova. The Russians and the Anglo-Boer War, 1899-1902. Cape

Town: Human \& Rousseau, 1998, 89-98.

${ }^{35}$ TCD. Davitt papers. File Ms 9527, 25 April 1900.

${ }^{36}$ The Saturday Review. 20 June 1908.

${ }^{37}$ Personal correspondence, Patrick Maume to Donal McCracken, 22 January 2015; Saturday Review. 20 June 1908. 781-782.

${ }^{38}$ King Michael Davitt ... op. cit., pp. 478-479.

${ }^{39}$ The only other known photograph of Davitt on horseback shows him on a tourist hack on the Mount of Olives in Jerusalem in 1885.

${ }^{40}$ TCD. Davitt papers. File Ms 9573, 14 May 1900.

${ }^{41}$ Ibid.

${ }^{42}$ DP McCracken. Teddy Luther's war: The diary of a German-American in an IrishBoer commando. Pinetown: 30 Degrees South, 2013, 18-30.

${ }^{43}$ TCD. Davitt papers. File: Ms 1803, Davitt to John Dillon, 4 April 1900.

${ }^{44}$ Daily Graphic. 28 August 1896.

${ }^{45}$ National Library of Ireland. Allen papers. File: Ms 26 757, Davitt to John MacBride, 7 April [1900]. 
${ }^{46}$ Blake and MacBride's commando at any one time in the opening months of its existence had about 250 men and Lynch's about 50 men.

${ }^{47}$ For the later part of the Irish commando's existence, see McCracken, Teddy Luther's war ... op. cit.

${ }^{48}$ Glencoe was a small coal-mining town in northern Natal, only a few miles from where the battle of Talana was fought in October 1899. Being the railhead of a spur line of the main Durban-Johannesburg railway, it had great strategic importance.

${ }^{49}$ McCracken, "From Paris to Paris ..." op . cit., p. 133.

${ }^{50}$ TCD. Davitt papers. File 9592, 4 May 1900.

${ }^{51}$ TCD. Davitt papers. File Ms 9592, 5 May 1900.

${ }^{52}$ TCD. Davitt papers. File Ms 9592, 7 May 1900.

${ }^{53}$ TCD. Davitt papers. File: Ms 1805.

${ }^{54}$ The Saturday Review. 20 June 1908.

${ }_{55}$ TCD. Davitt papers. File: Ms 9573, f. 24, 15 April 1900.

${ }^{56}$ South African Archives, Pretoria. Files: OD, OR 4167/00, 1900; SP, GDDM 91/00, 10 May 1900; SSA, RA 2623/00, 19 May 1900.

${ }^{57}$ TCD. Davitt papers. File Ms 1811, 23 June 1900.

${ }^{58}$ TCD. Davitt papers. File: Ms 9573, ff. 67.

${ }^{59}$ A statue of Robert Emmet stood for a number of years in the Eastern Cape town of Uitenhage, and an Afrikaans-speaking branch of the family (spelled Emmett) lived in Natal.

${ }^{60}$ TCD. Davitt papers. File: Ms 9592, f. 60b.

${ }^{61}$ Ibid., File: Ms 9573, f. 21b-22.

${ }^{62}$ TCD. Davitt papers. File 9572, 8 March 1900.

${ }^{63}$ Marley op. cit., pp. 251, 255.

${ }^{64}$ TCD. Davitt papers. File 9592, f. 23.

${ }^{65}$ TCD. Davitt papers. File: Ms 9573, f. 25.

${ }^{66}$ TCD. Davitt diary, 9572/1, n.d., f. 103. Swaziland was controlled by the South African Republic as a protectorate from 1904 until 1900.

${ }^{67}$ DP McCracken. "The Irish Republican Association of South Africa, 1920-2". Southern African-Irish Studies 3. 1996. 55-58.

${ }^{68}$ United Ireland. 9 November 1899.

${ }^{69}$ TCD. Davitt diary, Ms 9572/1, n.d., f. 97.

${ }^{70}$ J Lehmann. The first Boer War. London: Military Book Society, 1972, 118.

${ }^{71}$ TCD. Davitt papers. File Ms 9572, f. 102.

${ }^{72}$ LS Amery (ed). The Times History of the South African War 1899-1902, vol.

7. London: Simpson, Low, Marston \& Co., 1909, 17-23; DP McCracken. "Irish prisoners of war in the Anglo-Boer war". Irish Sword 31/126. Winter 2018. 391-421.

${ }^{73}$ TCD. Davitt papers. File 9572, f. 124.

${ }^{74}$ TCD. Davitt papers. File 9592, f. 4.

${ }^{75}$ Freeman's Journal. 8 March 1900.

${ }^{76}$ TCD. Davitt papers, Davitt to Dillon, 9 July 1901.

${ }^{77}$ Ibid. File: Ms 9592/2, diary, 4 May 1900. 
${ }^{78}$ HJ Batts. Pretoria from within, during the war, 1899-1900. London: John F. Shaw, 1900, 136-141, 230.

${ }^{79}$ King Michael Davitt ... op. cit., pp. 491-492.

${ }^{80} \mathrm{Ibid}$.

${ }^{81}$ D Lowry. "“A fellowship of disaffection": Irish-South African relations from the Anglo-Boer war to pretoriastroika, 1902-91'. Eire-Ireland 12. 1992. 10522.

${ }^{82}$ W O'Brien. An olive branch in Ireland and its history. London: Macmillan, 1910, 107-109.

${ }^{83}$ McCracken, Forgotten protest ... op. cit., pp. 59-63; Lyons op. cit., pp. 36-41.

${ }^{84}$ United Irishman. 23 November 1901.

${ }^{85}$ McCracken, MacBride's Brigade ... op. cit., p. 89.

${ }^{86}$ RG Hackett. South African war books: An illustrated bibliography of English language publications relating to the Boer war of 1899-1902. London: Privately published, 1994.

${ }^{87}$ TCD. Davitt papers, Davitt to Dillon, 22 August 1902, quoted in McCracken, MacBride's Brigade ... op. cit., p. 155.

${ }^{88} \mathrm{JE}$ de la Rey. A woman's wanderings and trials during the Anglo-Boer War (transl. L Holz). London: T. Fisher Unwin, 1903; C de Wet. Three year' war. London: Constable, 1902.

${ }^{89}$ M. Davitt. Within the Pale: The true story of anti-Semitic persecutions in Russia. London: Hurst \& Blackett, 1903.

${ }^{90}$ DP McCracken. "The relationship between British war correspondents in the field and British Military Intelligence during the Anglo-Boer War". Scientia Militaria 43/1. 2015. 99-126.

${ }^{91}$ Lynch's article titled "En campagne avec les Boers: Notes critiques" appeared in the Revue de Paris on 1 October 1900. See P McCracken's translation and introduction in Southern African-Irish Studies 4. 2012. 69-80. MacBride's accounts in the Freeman's were published on 13, 20 and 27 October; 3, 10 and 17 November; 1 and 29 December 1906; 5 and 12 January; 9 February; 2 April; and 29 July 1907. These are reproduced in AJ Jordan. Boer War to Easter Rising: The writings of John MacBride. Westport: Westport Books, 2006.

92 TCD. Davitt papers. File 9411, 4 April 1900.

${ }^{93}$ National Archives of South Africa, Pretoria. Files SSA, RA 2131/00, 11 April 1900; SS, R7081x/00, 17 April 1900; SSA, RA 2419/00, 7 May 1900; SAA, RA 2468/00, 14 May 1900; SSA, RA 2496/00, 16 May 1900. Schlomer was proprietor from 1895 until 1907. Personal communication, Professor Fransjohan Pretorius to Donal McCracken, ${ }^{21}$ December 2014.

${ }^{94}$ L Dunston. Young Pretoria 1889-1913. Pretoria: Lola Dunstun, 1975, 69.

${ }^{95}$ Military notes on the Dutch Republics of South Africa. Compiled in Section B, Intelligence Division, War Office. London: War Office, 1898.

${ }^{96}$ DP McCracken. "John Ardagh (1840-1907): The Irish Intelligence scapegoat for Britain's Anglo-Boer War debacles". Études Irlandaises 38/1. 2013. 55-67; Davitt op. cit., pp. 58-65. 
${ }^{97}$ The Saturday Review. 20 June 1908

${ }^{98}$ Ibid.

${ }^{99}$ King Michael Davitt ... op. cit., p. 488.

${ }^{100}$ RF Foster. W.B. Yeats: A life. I: The apprentice mage 1865-1914. Oxford: Oxford University Press, 1997, 223.

${ }^{101}$ United Irishman. 24 February 1900.

${ }^{102}$ United Irishman. 20 October 1900; DP McCracken. Inspector Mallon. Dublin: Irish Academic Press, 2009, 114.

${ }^{103}$ National Archives, London. CO904/70, RIC monthly report, June 1902; Irish Independent. 9 June 1902.

${ }^{104}$ National Archives, Pretoria. Leyds Archive, Ierse Geheime Korrespondensie, vol. 191; McCracken, MacBride's Brigade ... op. cit., pp. 80-81.

${ }^{105}$ NLI. Redmond papers. File: Ms 15, 179 (ii), Davitt to John Dillon, 24 August 1902. 